\title{
Does Digitalization Lead to Better Transparency: Bibliometric Approach
}

\author{
http://doi.org/10.21272/bel.5(3).102-107.2021
}

Pavlo Kostetskyi, ORCID: https://orcid.org/0000-0003-0654-2153

Director of Project Development with African countries, Akkona Sp. z o. o., Warsaw, Poland

\begin{abstract}
In recent years, digitalization has been an important factor in developing political, economic, social, and cultural relations. The rapid growth of digital technologies in global and national contexts leads to significant quantitative and qualitative changes in the economic development of countries. Digitalization leads to better transparency and is also related to new damages to the national economy. Thus, this research deals with the identification of interconnectedness between digitalization and transparency. Fulfillment of this task is realized with the VOSviewer bibliometric tool based on the analysis of 320 Scopus articles on "transparency" and "digitalization" in 1999-2021. Analysis of the dynamic of publications on transparency and digitalization allows concluding that there were only several publications a year in 1999-2009. In 2010-2018 the number of relevant publications demonstrated considerable growth, while in 2019-2021, there was a boost of scientific interest to the cohesion between transparency and digitalization. The bibliometric analysis allows pointing out that there is a strong relationship between transparency and digitalization. Basically, under network analysis, six clusters of research were identified, which focused on the implementation of digital technologies in business, logistics, public governance, the financial sphere, information management, and personal privacy. Moreover, considering visualization results, it might be concluded that more recent publications on transparency and digitalization are focused on the research of blockchain technologies, supply technologies, and artificial intelligence. The density visualization showed that the most relevant keywords in publications on transparency and digitalization are digitalization, blockchain, and industry 4.0. These bibliometric results might create a theoretical background on clarification of scale up to which development of digital sphere does not damage national security.
\end{abstract}

Keywords: Bibliometric Analysis, Digitalization, Transparency, Transformations.

JEL Classification: D80, F50, H10.

Cite as: Kostetskyi, P. (2021). Does Digitalization Lead to Better Transparency: Bibliometric Approach. Business Ethics and Leadership, 5(3), 102-107. http://doi.org/10.21272/bel.5(3).102-107.2021.

Received: 12 June 2021

Accepted: 08 August 2021

Published: 13 September 2021

Copyright: (C) 2021 by the author. Licensee Sumy State University, Ukraine. This article is an open access article distributed under the terms and conditions of the Creative Commons Attribution (CC BY) license (https://creativecommons.org/licenses/by/4.0/).

\section{Introduction}

The globalization of the national economy actualizes the strengthening of intersectional ties, which leads to significant structural transformations. The formation of the post-industrial economy relates to the information technology development, which provoked significant economic transformations, particularly, the active development of services, including high-tech, reduces the role of the real sector, the emergence of new businesses and modification of existing ones using the new technological revolution. The growing role of the digital economy is shaping new demands on the labor market the emergence of new professions, the increasing role of digital skills and soft skills.

Notably, the effects of digitalization have led to changes in the security strategy of the national economy. Thus, along with the emergence of such new vectors as data security and information security, it should be noted the growing importance of digital technologies in ensuring the standard components of national security economic, social and information. It requires the transformation of existing approaches to overcoming the security challenges of the national economy in the context of increasing the complexity of the strategic vision, considering the transmission links that arise between the elements of security of the national economy. Moreover, one should note that the intensive development of digital technologies leads to more transparency, but it also triggers new damages to national security. Therefore, it is necessary to clarify the scale to which digital sphere development does not damage national security. However, an essential task from both a 
theoretical and a practical point of view is identifying the relationship between digitalization and transparency, which can help identify this scale.

\section{Literature Review}

One should note that there are an increasing number of scientific publications and analytical reports on the role of digitalization in different spheres and also on the necessity of transparency and accountability in ensuring sustainable development, but there is a lack of publications on the interconnectedness of digitalization and transparency. Andersen and Motzfeldt (2019) researched how transparency influences the efficiency of egovernance in Denmark. The authors specify that a lack of transparency led to a decrease in population loyalty. They pointed out that it is dramatically important for effective e-governance to have "transparency of algorithms, and data, as well as transparency of administrative decisions, and democratic debate". Kolukirik (2021) described how digitalization and transparency became an integral part of citizens' everyday lives, pointed out its preconditions and consequences in this respect.

In the publication of the Division of Innovations to Serve the Citizen of the Inter-American Development Bank (2021), it is mentioned that digitalization and transparency help both business and public authorities to be more effective and competitive. It is also pointed out that effective digital delivery of public services is an essential competitive advantage in terms of COVID-19 pandemic overcoming. It is argued that "digital transformation has the potential to unleash a paradigm shift in the relationship between the state and citizens by accelerating the advancement of more inclusive, transparent, and efficient development in a region". The Civil Society \& Think Tank Forum I (2021) mentioned that digitalization led to better transparency, and there are no more borders between the real and digital sectors. This report also noted that among core advantages of digitalization there is " $24 / 7$ accessibility even during the pandemic, citizens spending about $50 \%$ less time spent interacting with public administration, more than a 50\% decrease in costs for companies interacting with public administration, and $60 \%$ less case-handling efforts".

Jonak, Rudnicka, and Włoch (2020) analyzed how digitalization helps to improve supply chain transparency. Authors mentioned that new digital technologies dramatically change the whole paradigm of business functioning - from production technologies to logistics, etc. Kayikci (2018) also pointed out that digitalization plays a crucial role in transforming the logistic process. It helps to make the whole logistic more transparent for suppliers and customers. The paper "Digitization and transparency - transforming the future of corporate governance?" (2016) focuses on the statement that transparency is a necessary precondition of good corporate governance, while the last one is impossible without digital technologies. Good corporate governance might help businesses to attract investment. In turn, businesses become more visible and aware to different groups of stakeholders by dint of digitalization.

\section{Methodology and Results}

Research of the interconnectedness between "transparency" and "digitalization" is realized with VOSviewer (Figure 3) and consider results of bibliometric analysis of 320 publications in Scopus on relevant topic in 19992021 (Figure 1, 2).

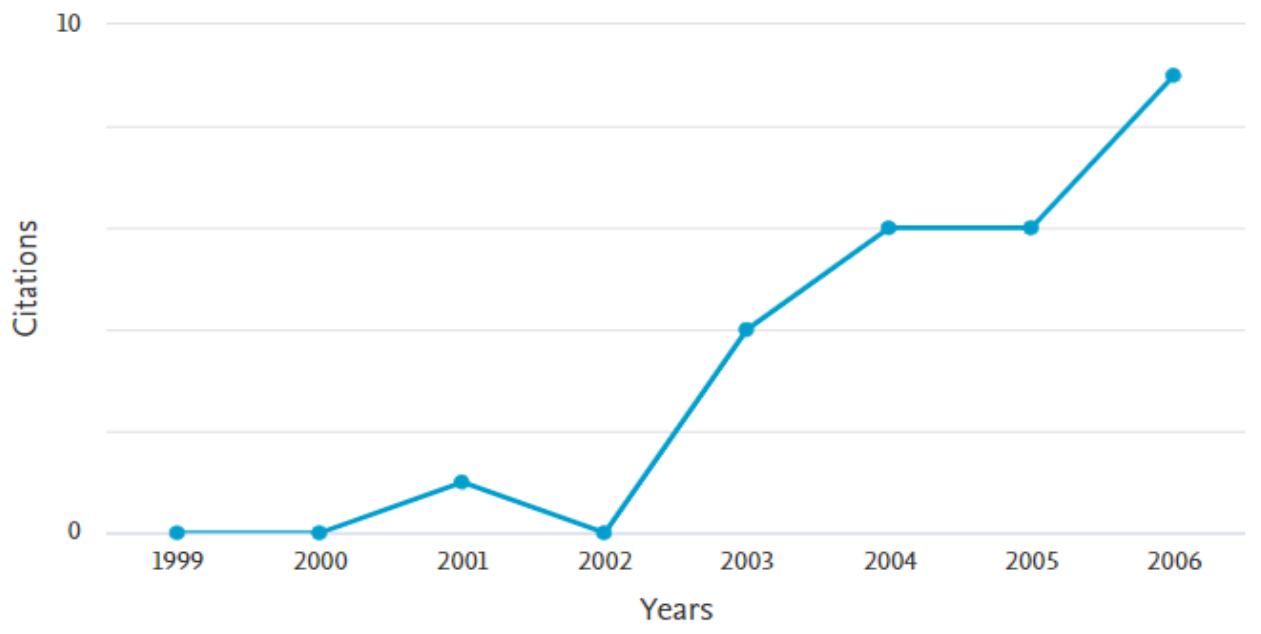

Figure 1. The Dynamic of Articles on Transparency and Digitalization Published in Scopus in 1999-2006, Amount of Articles Source: Scopus, 2021 


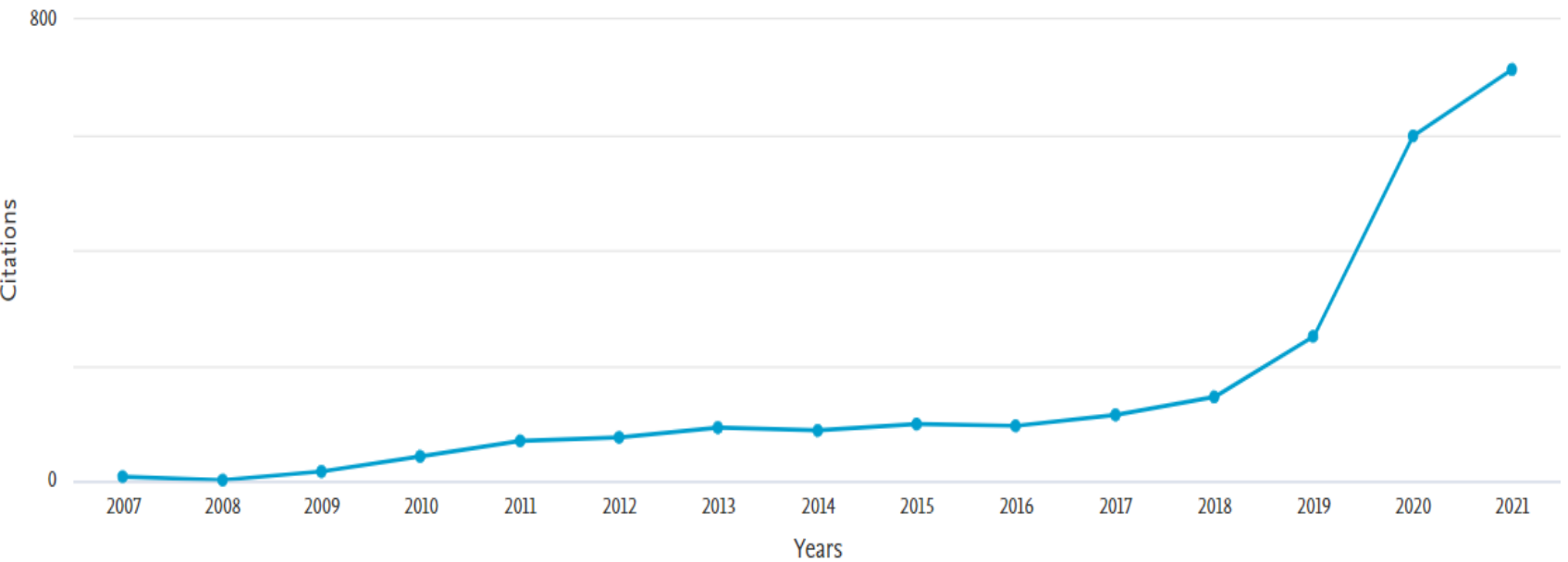

Figure 2. The Dynamic of Articles on Transparency and Digitalization Published in Scopus in 2007-2021, Amount of Articles Source: Scopus, 2021

Analysis of the dynamic of publications on transparency and digitalization allows concluding that there were only several publications a year in 1999-2009, but in 2010-2018, the amount of relevant publications demonstrated a considerable growth, while in 2019-2021, there was a boost of scientific interest to the problem of cohesion between transparency and digitalization.

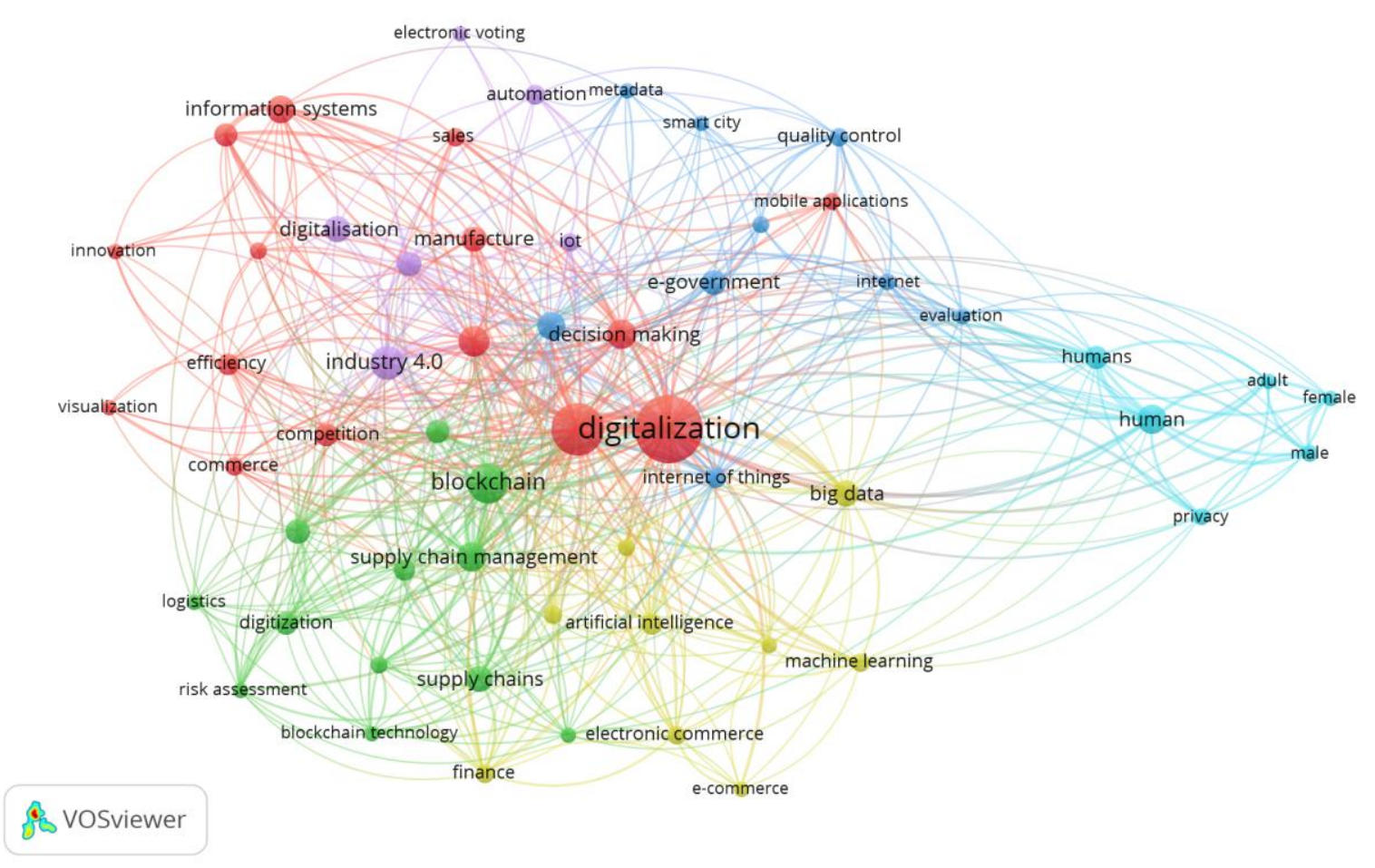

Figure 3. Results of VOSviewer Analysis of Scopus Articles on Transparency and Digitalization in 1999-2021 (Network Visualization)

Source: VOSviewer, 2021

Thus, VOSviewer analysis allows underlining existence of 6 clusters of scientific research on transparency and digitalization such as:

cluster 1 (red) covers researches with such keywords as commerce, competition, costs, decision making, digital technologies, digitalization, efficiency, information system, information use, innovation, manufacture, mobile applications, sales, transparency, visualization; 
cluster 2 (green) - agriculture, blockchain, blockchain technologies, digital economy, digitalization, logistics, risk assessment, smart contracts, supply chain management, supply chain, sustainability, sustainable development;

cluster 3 (dark blue) - digital transformation, e-governance, internet, internet of things, metadata, public administration, quality control, smart city;

$>$ cluster 4 (yellow) - artificial intelligence, big data, e-commerce, economics, electronic commerce, finance, investments, machine learning, service industry;

$>$ cluster 5 (violet) - automation, digitalization, electronic voting, industry 4.0, information management;

cluster 6 (light blue) - adult, male, female, human, privacy.

Therefore, it can be concluded that there are clusters of publications focused on implementation of digital technologies in business, logistics, public governance, financial sphere, information management, and personal privacy. Figure 4 illustrates overlay visualization of keywords publications in Scopus on transparency and digitalization in 1999-2021.

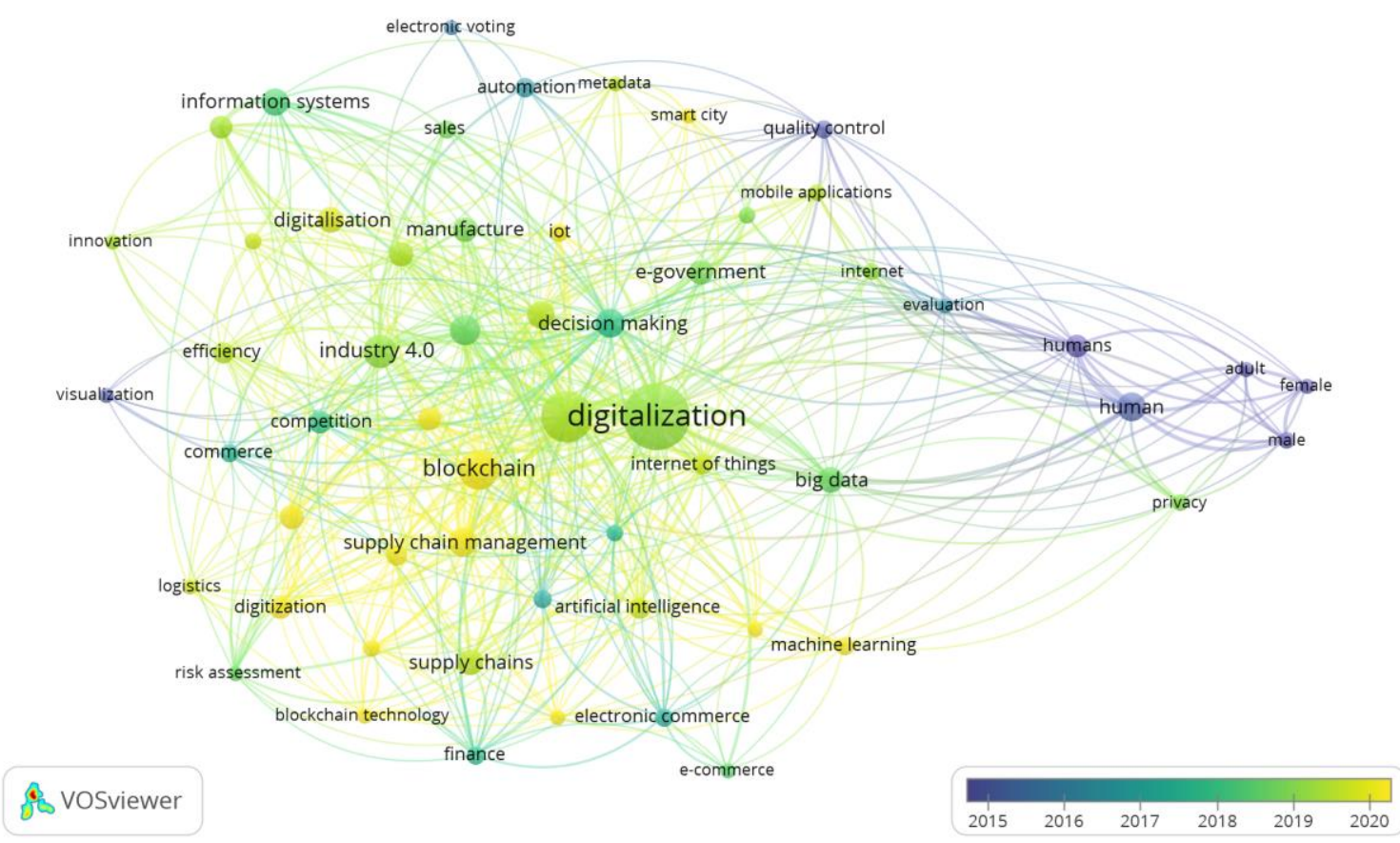

Figure 4. Results of VOSviewer Analysis of Scopus Articles on Transparency and Digitalization in 1999-2021 (Overlay Visualization)

\section{Source: VOSviewer, 2021}

Considering visualization results, it might be concluded that more recent publications on transparency and digitalization are focused on research of blockchain technologies, supply technologies, and artificial intelligence. Density visualization of keywords publications in Scopus on transparency and digitalization in 1999-2021 are presented on Figure 5. 


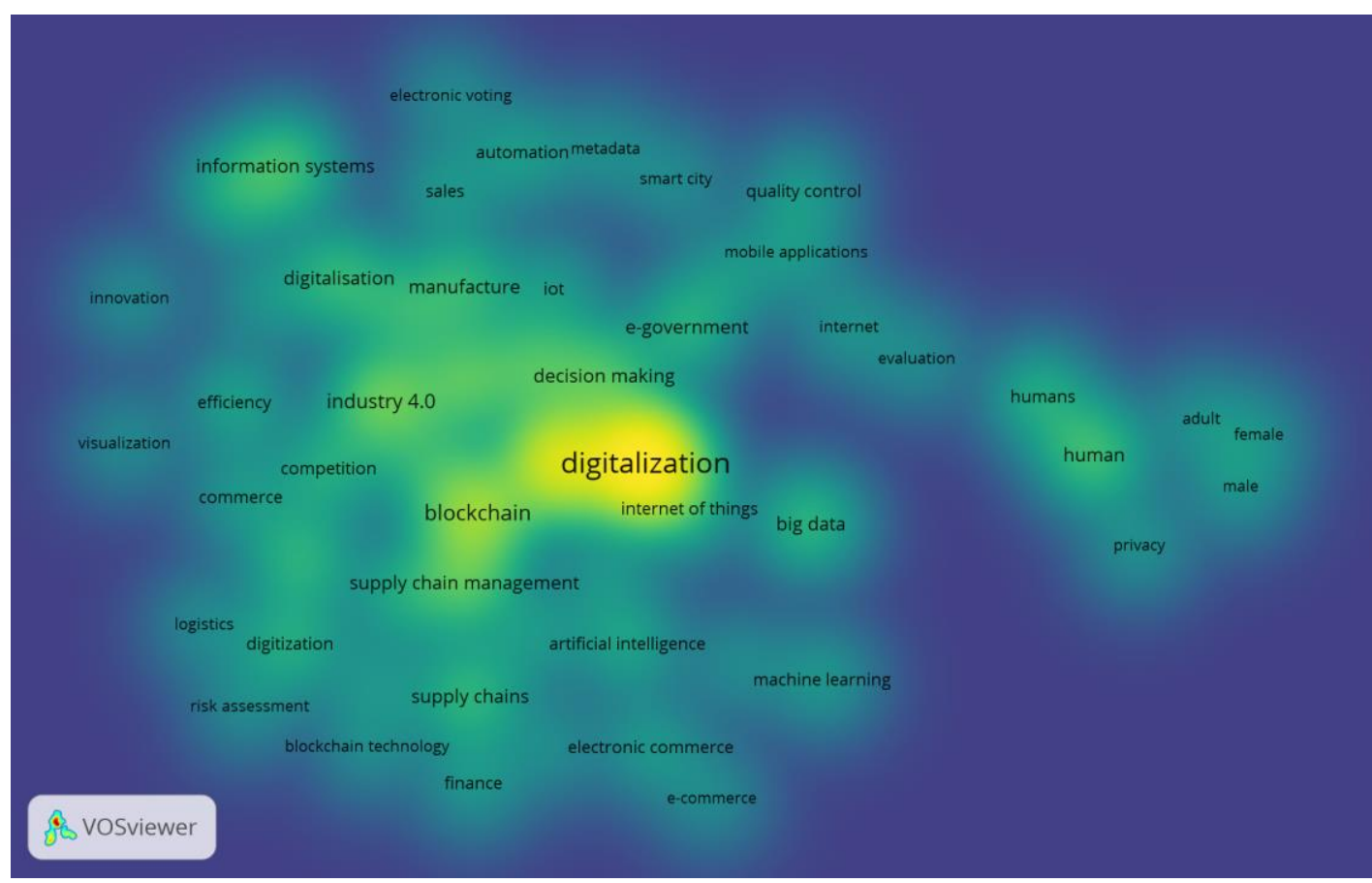

Figure 5. Results of VOSviewer Analysis of Scopus Articles on Transparency and Digitalization in 1999-2021 (Density Visualization)

Source: VOSviewer, 2021

Figure 5 demonstrates that the most relevant keywords in publications on transparency and digitalization are digitalization, blockchain, and industry 4.0. Table 1 describes the ten most cited publications on transparency and digitalization. As far as we can see from the table, most scientific publications interconnectedness of transparency and digitalization focused on their role in business management, logistics, e-governance, blockchain technologies and data safety and management.

Table 1. Top 10 Scopus most cited publications on transparency and digitalization

\begin{tabular}{|c|c|c|c|c|c|}
\hline № & Publication title & Author(s) & Year & Source & Citations \\
\hline 1 & $\begin{array}{l}\text { Polymers for flexible displays: From material selection to } \\
\text { device applications }\end{array}$ & $\begin{array}{l}\text { Choi, M.-C., } \\
\text { Kim, Y., } \\
\text { Ha, C.-S. }\end{array}$ & 2008 & $\begin{array}{l}\text { Progress in Polymer Science } \\
\text { (Oxford) 33(6), pp. 581-630 }\end{array}$ & 720 \\
\hline 2 & $\begin{array}{l}\text { Understanding blockchain technology for future supply } \\
\text { chains: a systematic literature review and research agenda }\end{array}$ & $\begin{array}{c}\text { Wang, Y., } \\
\text { Han, J.H., } \\
\text { Beynon-Davies, P. }\end{array}$ & 2019 & $\begin{array}{c}\text { Supply Chain Management } \\
24(1), \text { pp. } 62-84\end{array}$ & 202 \\
\hline 3 & $\begin{array}{l}\text { Securing e-Government and e-Voting with an open cloud } \\
\text { computing architecture }\end{array}$ & $\begin{array}{l}\text { Zissis, D., } \\
\text { Lekkas, D. }\end{array}$ & 2011 & $\begin{array}{c}\text { Government Information } \\
\text { Quarterly 28(2), pp. 239-251 } \\
\end{array}$ & 128 \\
\hline 4 & Sustainability impact of digitization in logistics & Kayikci, Y. & 2018 & $\begin{array}{l}\text { Procedia Manufacturing } \\
\text { 21, pp. } 782-789 \\
\end{array}$ & 92 \\
\hline 5 & $\begin{array}{l}\text { Defining digital transformation: Results from expert } \\
\text { interviews }\end{array}$ & $\begin{array}{l}\text { Mergel, I., } \\
\text { Edelmann, N., } \\
\text { Haug, N. }\end{array}$ & 2019 & $\begin{array}{l}\text { Government Information } \\
\text { Quarterly 36(4),101385 }\end{array}$ & 83 \\
\hline 6 & $\begin{array}{l}\text { Blockchain technology in the oil and gas industry: A review of } \\
\text { applications, opportunities, challenges, and risks }\end{array}$ & $\begin{array}{l}\text { Lu, H., } \\
\text { Huang, K., } \\
\text { Azimi, M., } \\
\text { Guo, L. }\end{array}$ & 2019 & $\begin{array}{c}\text { IEEE Access 7,8675726, pp. } \\
41426-41444\end{array}$ & 65 \\
\hline 7 & $\begin{array}{l}\text { Radiochromic film dosimetry: Considerations on precision } \\
\text { and accuracy for EBT2 and EBT3 type films }\end{array}$ & $\begin{array}{l}\text { Dreindl, R., } \\
\text { Georg, D., } \\
\text { Stock, M. }\end{array}$ & 2014 & $\begin{array}{l}\text { Zeitschrift fur Medizinische } \\
\text { Physik 24(2), pp. 153-163 }\end{array}$ & 58 \\
\hline 8 & $\begin{array}{l}\text { Big data and organizational design - the brave new world of } \\
\begin{array}{l}\text { algorithmic management and computer augmented } \\
\text { transparency }\end{array}\end{array}$ & Schildt, H. & 2017 & $\begin{array}{l}\text { Innovation: Management, } \\
\text { Policy and Practice } \\
\text { 19(1), pp. 23-30 }\end{array}$ & 52 \\
\hline 9 & $\begin{array}{l}\text { Empirical assessment of the future adequacy of value stream } \\
\text { mapping in manufacturing industries }\end{array}$ & $\begin{array}{l}\text { Lugert, A., } \\
\text { Batz, A., } \\
\text { Winkler, H. }\end{array}$ & 2018 & $\begin{array}{l}\text { Journal of Manufacturing } \\
\text { Technology Management } \\
\text { 29(5), pp. 886-906 }\end{array}$ & 46 \\
\hline 10 & $\begin{array}{l}\text { A framework for food supply chain digitalization: lessons from } \\
\text { Thailand }\end{array}$ & $\begin{array}{l}\text { Kittipanyangam P., } \\
\text { Tan, K.H. }\end{array}$ & 2020 & $\begin{array}{c}\text { Production Planning and } \\
\text { Control 31(2-3), pp. 158-172 }\end{array}$ & 45 \\
\hline
\end{tabular}

Source: Scopus, 2021 


\section{Conclusions, Discussion and Recommendations}

Thus, according to the study results, there is a close relationship between digitalization and transparency, as the development of digital technologies, on the one hand, contributes to improving publicity, accountability, and transparency. At the same time, digitalization improves the transparency and efficiency of the business model and the system of public administration. According to the results of bibliometric analysis of the keywords "transparency" and "digitalization", six clusters of research are identified and focused on the implementation of digital technologies in business, logistics, public governance, the financial sphere, information management, and personal privacy.

Funding. There is no funding for this research.

\section{References}

1. Andersen, A.N., \& Motzfeldt, H.M. (2019). Different aspects of transparency in digital government: The Danish case. In T. Kaya (Ed.), Proceedings of the 19th European Conference on Digital Government, ECDG 2019 (pp. 81-88). Academic Conferences Limited. Proceedings of the European Conference on e-Government, ECEG Vol. 2019-October. [Google Scholar] [CrossRef]

2. Choi, M.-C., Kim, Y., Ha, C.-S. (2008). Polymers for flexible displays: From material selection to device applications. Progress in Polymer Science (Oxford), 33(6), 581-630. [Google Scholar] [CrossRef]

3. Civil Society \& Think Tank Forum I (2021). Digitalization in Public Services: Enhancing Transparency, Securing Data Protection. Available at: [Link]

4. Digitization and transparency - transforming the future of corporate governance? (2016) 19th European Corporate Governance Conference Bratislava, 27 October 2016. Available at: [Link]

5. Division of Innovations to Serve the Citizen of the IDB (2021). Good digitalization does not happen on its own: it requires good human decisions. Available at: [Link]

6. Dreindl, R., Georg, D., \& Stock, M. (2014). Radiochromic film dosimetry: Considerations on precision and accuracy for EBT2 and EBT3 type films. Zeitschrift Fur Medizinische Physik, 24(2), 153-163. [Google Scholar] [CrossRef]

7. Jonak, Ł., Rudnicka, A., Włoch, R. (2020). Digitalization of supply chain transparency: the case of ChainReact. In: Grzybowska K. et al., editors. Sustainable logistics and production in Industry 4.0. Cham: Springer. p. 89-102. [Google Scholar] [CrossRef]

8. Kayikci, Y. (2018). Sustainability impact of digitization in logistics. Paper presented at the Procedia Manufacturing, 21, 782-789. [Google Scholar] [CrossRef]

9. Kittipanya-ngam, P., \& Tan, K.H. (2020). A framework for food supply chain digitalization: Lessons from Thailand. Production Planning and Control, 31(2-3), 158-172. [Google Scholar] [CrossRef]

10.Kolukirik, S. (2021). Digitalization and Future of Digital Society. Berlin, Germany: Peter Lang Verlag. Retrieved Oct 5, 2021. Available at: [Link]

11.Lu, H., Huang, K., Azimi, M., \& Guo, L. (2019). Blockchain technology in the oil and gas industry: A review of applications, opportunities, challenges, and risks. IEEE Access, 7, 41426-41444. [Google Scholar] [CrossRef]

12.Lugert, A., Batz, A., \& Winkler, H. (2018). Empirical assessment of the future adequacy of value stream mapping in manufacturing industries. Journal of Manufacturing Technology Management, 29(5), 886-906. [Google Scholar] [CrossRef]

13.Mergel, I., Edelmann, N., \& Haug, N. (2019). Defining digital transformation: Results from expert interviews. Government Information Quarterly, 36(4), 101385. [Google Scholar] [CrossRef]

14.Schildt, H. (2017). Big data and organizational design-the brave new world of algorithmic management and computer augmented transparency. Innovation: Management, Policy and Practice, 19(1), 23-30. [Google Scholar] [CrossRef]

15.Scopus (2020). Available at: [Link]

16.VOSviewer (2020). Available at: [Link]

17.Wang, Y., Han, J.H., \& Beynon-Davies, P. (2019). Understanding blockchain technology for future supply chains: A systematic literature review and research agenda. Supply Chain Management, 24(1), 62-84. [Google Scholar] [CrossRef]

18.Zissis, D., \& Lekkas, D. (2011). Securing e-government and e-voting with an open cloud computing architecture. Government Information Quarterly, 28(2), 239-251. [Google Scholar] [CrossRef] 